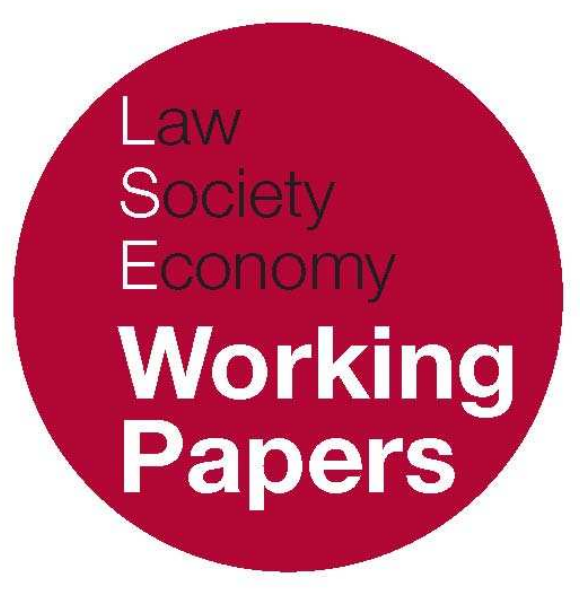

\title{
Life After Work: Privacy and Dismissal
}

\author{
Virginia Mantouvalou
}

LSE Law, Society and Economy Working Papers 5/2008

London School of Economics and Political Science

Law Department

This paper can be downloaded without charge from LSE Law, Society and Economy Working Papers at: www.lse.ac.uk/collections/law/wps/wps.htm and the Social Sciences Research Network electronic library at: http://ssrn.com/abstract $=1111957$.

(C) Virginia Mantouvalou. Users may download and/or print one copy to facilitate their private study or for non-commercial research. Users may not engage in further distribution of this material or use it for any profit-making activities or any other form of commercial gain. 


\title{
Life After Work: Privacy and Dismissal
}

\author{
Virginia Mantouvalou
}

\begin{abstract}
This article addresses the issue of termination of employment because of the conduct of the employee in her leisure time, in the light of the human right to private life. It explores the impact on the retention of employment of activities taking place outside the workplace and outside working hours, and argues that the approach of domestic courts and tribunals on the matter, which is based on a spatial conceptualisation of privacy, is flawed. Having analysed the reasons why the current interpretation of privacy is wanting, the paper suggests a fresh approach, which rests on the idea of domination that the employer can exercise on the employee. The paper's proposition is based on an interpretation of the right to privacy as a right to control information, rather than a right to act in spatial isolation. It argues that life after work may lead to lawful dismissal only if there is a clear and present impact or a high likelihood of such impact on employment, whilst a speculative and marginal danger does not suffice.
\end{abstract}

\section{INTRODUCTION}

Driving back home on a winter Saturday night, Mr X stopped at a transport café between two towns to use the lavatory. In the toilet he met a man with whom he had consensual sex. A police officer entered the toilet and arrested them both. $\mathrm{Mr}$ $\mathrm{X}$, 'very shocked and frightened', ${ }^{1}$ was driven to the police and put in a cell. $\mathrm{He}$ was interviewed and was reassured that further action would not be taken unless

\footnotetext{
${ }^{*}$ Lecturer in Law, University of Leicester and member of the LSE International Humanitarian Law project. Grateful thanks are due to Nicos Alivizatos, Harry Arthurs, Julia Black, David Bonner, Leto Cariolou, Colm O'Cinneide, Hugh Collins, Nicholas Hatzis, Dimitris Kyritsis, Stuart Lakin, George Letsas and Erika Szyszczak for comments on a draft of this article. Earlier versions were presented at the 2007 Society of Legal Scholars Conference in Durham, a staff seminar at the University of Bristol and the LSE Cumberland Lodge away weekend. I am deeply thankful to Mark Bell, Steven Greer, Pascale Lorber, Tonia Novitz, Achilles Skordas, Charlie Webb, Mike Wilkinson and all participants for their comments and suggestions.

${ }^{1}$ X v Y [2004] ICR 1634, Brooke LJ, [75].
} 
he re-offended within five years. Having been cautioned for gross indecency, his name was placed on the Sex Offenders Register. His offence was to have engaged in homosexual activity in public with a consenting adult. Mr X was employed by a charity organising activities for young offenders. His employer, who had access to the Register, was informed of the offence. Mr X was dismissed.

Mr Pay performed shows in hedonist and fetish clubs in his leisure time and was also a director of a company selling products connected with bondage and sadomasochism on the internet; photographs of him and semi-naked women and men were available online. Mr Pay was employed as a probation officer. At some point he disclosed to his employer that he belonged to a number of organisations, and the employer was later informed about his activities in detail. Although none of his private activities had an impact on his performance at work, the employer held the view that they were incompatible with his professional duties as a probation officer. Mr Pay was dismissed.

Was the dismissal of Mr Pay and Mr X lawful? Or, to widen our focus, may a person lose her job due to the way she conducts herself in her leisure time, or for reasons connected with her intimate relationships? The point of this article is to address this question by exploring the protection of the right to private life in employment, an admittedly rich and complex subject. My analysis does not examine all aspects of workplace privacy, but explores a specific issue: that of the impact on the retention of employment of activities taking place outside the workplace and outside working hours. This is an aspect of the interrelationship between work and private life that has been insufficiently analysed in the academic literature, which usually discusses privacy within the workplace and working hours. ${ }^{2}$ Yet this matter warrants separate consideration given the potentially grave implications for individual autonomy and social interaction if it is left unregulated. In this regard, my purpose is to assess the legality of a dismissal resulting from the fact that an employer disapproves of the conduct of the employee, either because the employer believes that the behaviour in question may have a negative effect on the business, or because it rejects it as a personal choice on moral or other grounds.

\footnotetext{
2 See J.D.R. Craig, Privacy and Employment (Oxford: Hart, 1999), M. Ford, 'Two Conceptions of Worker Privacy', (2002) 31 ILJ 135, H. Oliver, 'Email and Internet Monitoring in the Workplace: Information Privacy and Contracting Out' (2002) 31 ILJ 321, A. McColgan, 'Do Human Rights Disappear in the Workplace', (2003) EHRLR supplement (special issue) 119. For a recent analysis, see M. Freedland, 'Privacy, Employment and the Human Rights Act 1998' in K. Ziegler (ed.), Human Rights and Private Law (Oxford: Hart, 2007) 141. For the German approach see, in the same collection, M. Coester, 'Protection of Employees' Individual Rights in the Employer-Employee Relationship', 133. For an overview of the debates in the US, see A. Bernstein, 'Foreword: What We Talk About When We Talk About Workplace Privacy' (2005-2006) 66 Louisiana Law Review 923. This issue of the Lonisiana Law Review includes a number of articles that deal with different aspects of the topic. The article 'Life Away from Work', by M.W. Finkin, 945, of the issue is a comparative analysis that focuses on activities after work and their impact on the retention of employment, without looking at the example of the UK. On the position in France, see the special issue of the (2004) Droit Social, entitled 'Vie Professionnelle et Vie Personnelle'.
} 
To develop my argument, I first examine the decisions of UK courts and tribunals in the cases of $X \mathrm{v} Y^{3}$ and Pay v Lancashire Probation Service, ${ }^{4}$ the facts of which have been discussed above, with a view to identifying the main criterion articulated in judicial reasoning when looking at privacy and dismissal. This criterion is based on a spatial conceptualisation of private life, which implies that activities occurring in a public space cannot constitute elements of the employee's private life. My position is that the spatial conception of the right to private life is erroneous.

We cannot advance a fresh suggestion without an analysis of the value of privacy. Indeed, privacy has been explored in depth in philosophical and legal discourse and, importantly for present purposes, the academic literature suggests that the content of the right is contextually-dependent. And yet its value has not been thoroughly thought through in UK employment law. Can we therefore reinterpret the right to privacy, in a way that will be more suitable for the employment relationship? My suggestion is to conceive of the right to privacy as $a$ strong right of the employee to control information on her life after work against employer interference. This argument rests on the idea of domination. It is triggered by the proposition that in the employment context, the character of the contractual relationship that has economic dependence at its heart allows the employer to exercise a dominating power on the employee. Yet it is precisely because an employee's behaviour outside the workplace and working time is most probably not linked to the performance of contractual duties, that it can fairly be argued that it forms an illegitimate reason for dismissal. Indeed, this view has been embraced by several national and supranational legal orders. The basic premise of my proposition, I ought to note from the outset, embraces activities after work, without necessarily applying to all aspects of the delicate interaction between work and privacy. Some deeper understanding of the theoretical issues, though, may have a direct bearing on the analysis of the protection of privacy within the workplace too.

\section{PRIVACY AND DISMISSAL}

Mr X and Mr Pay, the employees of the examples that introduced the present article, challenged the legality of their dismissal, ${ }^{5}$ claiming that it did not satisfy the test of fairness under the Employment Rights Act 1996 (ERA). The ERA recognises a right to be protected against unfair dismissal in Part 10. Section 94(1) provides that '(a)n employee has the right not to be unfairly dismissed by his

\footnotetext{
${ }^{3} X_{\mathrm{v}} Y$ [2004] ICR 1634, hereinafter cited as Xv Y.

4 Pay v Lancashire Probation Service [2004] ICR 187, hereinafter cited as Pay.

${ }^{5}$ See $\mathrm{n} 3$ and 4 above. These decisions have attracted some attention in literature. See, among others, H. Collins, 'The Protection of Civil Liberties in the Workplace' (2006) 69 MLR 619, and L. Vickers, 'Unfair Dismissal and Human Rights' 33 (2004) ILJ 52.
} 
employer', who needs to present a reason for dismissal that may be 'conduct' or 'some other reason of a kind such as to justify the dismissal of an employee holding the position which the employee held'.6 According to section 98(4) that deals with fairness:

Where the employer has fulfilled the requirement of subsection (1), the determination of the question whether the dismissal is fair or unfair (having regard to the reason shown by the employer) - (a) depends on whether in the circumstances (including the size and administrative resources of the employer's undertaking) the employer acted reasonably or unreasonably in treating it as a sufficient reason for dismissing the employee, and (b) shall be determined in accordance with equity and the substantial merits of the case.

\section{Human Rights and REASONABLENESS IN Dismissal}

The threshold of fairness in dismissal was traditionally set low in English law. ${ }^{7}$ Employment tribunals and courts implemented a test of reasonableness, holding that termination of employment was lawful insofar as the decision was not unreasonable. ${ }^{8}$ The prospects of success for a claim challenging the legality of dismissal for activities that could be classified as private were slim. In 1975, for instance, in Spiller $\mathrm{v} W$ allis $L t d^{9}$ the employer, a supermarket, dismissed Mrs Spiller for having adulterous relationships contrary to the company policy. Her dismissal was held to be fair. In Mathewson v RB Wilson Dental Laboratories, ${ }^{10}$ the applicant was caught with cannabis while outside the workplace and working time. The court found his resulting dismissal 'harsh but fair'. In Saunders v Scottish National Camps Association, ${ }^{11}$ the applicant's dismissal on the grounds of his homosexuality was deemed to be equally unproblematic. Activities outside work formed the basis for a justified reason for termination of employment, while considerations of the implications for the employees' private life were probably irrelevant when determining legality. ${ }^{12}$

But Mr X and Mr Pay introduced a novel human rights argument in challenging the lawfulness of their dismissal. ${ }^{13} \mathrm{Mr}$ Pay contended that the termination of his employment was unfair for it breached his right to private life, ${ }^{14}$ and $\mathrm{Mr} \mathrm{X}$ alleged that his dismissal constituted a discriminatory interference with his right to privacy. What was the legal basis of this claim? A legal right to private

\footnotetext{
${ }^{6}$ Sections 98(1) and 98(2).

${ }^{7}$ For an analysis and criticism, see H. Collins, Justice in Dismissal (Oxford: Clarendon Press, 1992).

${ }^{8}$ Foley v Post Office [2000] ICR 1283.

9 Spiller v FJ Wallis Ltd. [1975] IRLR 362 (IT).

10 Mathewson v RB Wilson Dental Laboratories [1988] IRLR 512 (EAT).

11 Saunders v Scottish National Camps Association Ltd [1980] IRLR 174 (Employment Appeal Tribunal), [1981] IRLR 277 (Court of Session).

${ }^{12}$ For criticism, see n 7 above, 7-9, 201-204.

13 For an insightful analysis of a human rights approach to labour law, see A.C.L. Davies, Perspectives on Labour Law (Cambridge: Cambridge University Press, 2004), Chapter 3.

${ }^{14} \mathrm{He}$ also alleged that there had been a breach of his freedom of expression.
} 
life was not one of the traditional civil liberties, protected under common law, ${ }^{15}$ where the right to privacy did not enjoy special protection until relatively recently, when the European Convention on Human Rights (ECHR or Convention) was incorporated into domestic law through the Human Rights Act 1998 (HRA or Act). Under the HRA, courts have no power to strike down legislation, deemed to be incompatible with it. ${ }^{16}$ Yet according to section 3, courts have a duty to interpret legislation in a way that is compatible with the incorporated rights, insofar as possible. ${ }^{17}$ Section 4 provides for the power of courts to issue a declaration of incompatibility, if legislation breaches the HRA.

Article 8 of the ECHR recognises a right to private life. It reads as follows:

1. Everyone has the right to respect for his private and family life, his home and his correspondence.

2. There shall be no interference by a public authority with the exercise of this right except such as is in accordance with the law and is necessary in a democratic society in the interests of national security, public safety or the economic well-being of the country, for the prevention of disorder or crime, for the protection of health or morals, or for the protection of the rights and freedoms of others.

Employment law scholars saw the incorporation of the HRA as a glimmer of light in the obscure area of reasonableness in dismissal. ${ }^{18}$ While the Act does not create a cause of action between private parties, having in other words no direct horizontal effect, ${ }^{19}$ it produces effects on the private sphere in different ways. Under section 3 domestic courts have a duty to interpret national legislation in a manner compatible with the HRA.20 In addition, section 6(1) states that '[i]t is

\footnotetext{
15 For an argument for the constitutional protection of privacy, see E. Barendt, 'Privacy as a Constitutional Right and Value' in P. Birks (ed.), Privacy and Loyalty (Oxford: Clarendon Press, 1997) 12. For the position pre-HRA, see Kaye v Robertson [1991] FSR 62. Post-HRA see Douglas v Hello! [2001] 2 WLR 992. For an analysis, see among others G. Phillipson, 'Transforming Breach of Confidence? Towards a Common Law Right of Privacy under the Human Rights Act' (2003) 66 MLR 726.

16 On this see D. Feldman, 'The Human Rights Act 1998 and Constitutional Principles' (1999) 19 Legal Studies 165. See also S. Greer, 'A Guide to the Human Rights Act 1998', (1999) 24 ELR 3. For a theoretical analysis of the HRA see C. Gearty, Principles of Human Rights Adjudication (Oxford: Oxford University Press, 2004).

${ }^{17}$ See D. Bonner, H. Fenwick, and S. Harris-Short, 'Judicial approaches to the Human Rights Act' (2003) 52 ICLQ 549 and A. Kavanagh, 'The Elusive Divide between Interpretation and Legislation under the Human Rights Act' (2004) 24 OJLS 259.

${ }^{18}$ See, for instance, K.D. Ewing, 'The Human Rights Act and Parliamentary Democracy' (1999) 62 MLR 79 at 89, M. Ford, 'Two Conceptions of Worker Privacy' (2002) 31 ILJ 135, 135-136.

${ }^{19}$ There is a wealth of literature and debate on the matter of horizontality. See, for instance, M. Hunt, 'The "Horizontal Effect" of the Human Rights Act' (1998) PL 423, Sir R. Buxton, 'The HRA and Private Law' (2000) 116 LQR 48, Sir H.W.R. Wade, 'Horizons of Horizontality' 116 LQR 217, G. Phillipson, 'The Human Rights Act, 'Horizontal Effect' and the Common Law: A Bang or a Whimper?' (1999) 62 MLR 824, N. Bamforth, 'The Application of the Human Rights Act 1998 to Public Authorities and Private Bodies' (1999) 58 CLJ 159, D. Oliver, 'The Human Rights Act and the Public Law/Private Law Divides' (2000) EHRLR 343, A.L. Young, 'Horizontality and the Human Rights Act 1998', in Human Rights and Private Law, n 2 above, 35.

${ }^{20}$ See Ghaidan v Godin-Mendoza [2004] UHKL 30.
} 
unlawful for a public authority to act in a way which is incompatible with one or more of the Convention rights'. The term 'public authorities' also includes courts and tribunals, which in the development of common law, have to take into account Convention rights. ${ }^{21}$ Although the Act has no direct horizontal effect, it maintains an indirect horizontal effect, giving courts the power to rely on the rights it enshrines, when interpreting existing legislation.

Importantly, in $X \vee Y$ and in Pay it was accepted that section 98 of the ERA should be interpreted in light of the HRA:

Some unfair dismissal cases, naturally attract arguments based on Convention rights and the HRA: the employee dismissed for refusing, on religious grounds, to work on a particular day (article 9); the employee dismissed for engaging in party politics (article 10); or the employee whose activities, even in the privacy of his own home, may constitute a criminal offence and lead to dismissal (article 8). In general, whenever HRA points are raised in unfair dismissal cases, the employment tribunals should properly consider their relevance, dealing with them in a structured way (though not necessarily at great length), even if it is ultimately decided that they do not affect the outcome of the claim for unfair dismissal. ${ }^{22}$

Additionally, because $\mathrm{Mr} \mathrm{X}$ was employed by a private sector organisation, a charity, one of the questions raised concerned the horizontal applicability of human rights law. Mummery LJ tackled horizontality, holding that it will frequently be hard to apply a different standard to private employers, ${ }^{23}$ and further suggesting that the horizontal effect of the HRA becomes even more pertinent when looking at article 8 of the ECHR, a provision that imposes positive obligations upon state authorities. ${ }^{24}$

\section{No Private Life}

Yet although the first part of the applicants' argument was successful, and courts and tribunals were willing to view violation of privacy as a weighty consideration in the interpretation of the condition of fairness, the substantive issue of whether the termination of employment breached the right to private life was not as straightforward.

In the case of $\mathrm{Mr} \mathrm{X}$ the court had to consider whether the claim that the offence for which the applicant was cautioned was a discriminatory interference with private life, and the legislation in question was section 13 of the Sexual Offences Act 1956, as amended by the Sexual Offences Act 1967 that did not treat homosexual activity between males and heterosexual relationships equally; it only

21 Section 6(3)(a) HRA.

22 Mummery LJ, Xv Y, [49].

23 ibid, [57(4)].

24 ibid, [58(4)]. 
banned sexual intercourse between two men in public, while a similar activity between a man and a woman, or two women, remained legal. Article 14 of the ECHR prohibits discrimination without containing a free-standing equality clause. ${ }^{25}$ The Convention is violated when the alleged discriminatory act is related to the enjoyment of some other substantive right. In the interpretation of this other substantive provision though, the European Court of Human Rights (ECtHR or Court) does not seek to establish a breach; it suffices that the allegedly discriminatory act falls within its ambit. ${ }^{26}$

Was Mr X's right to private life engaged for the purposes of article 14? Mummery LJ's response was negative:

The applicant's conduct did not take place in his private life nor was it within the scope of application of the right to respect for it. It happened in a place to which the public had, and were permitted to have, access; it was a criminal offence, which is normally a matter of legitimate concern to the public; a criminal offence is not a purely private matter; and it led to a caution for the offence, which was relevant to his employment and should have been disclosed by him to his employer as a matter of legitimate concern to it. The applicant wished to keep the matter private. That does not make it part of his private life or deprive it of its public aspect. ${ }^{27}$

Mr X's dismissal was fair.

A similar argument was advanced when looking at the dismissal of Mr Pay, notwithstanding that he had not engaged in illegal conduct. Exploring section 98(4) of the ERA in the light of article 8 of the ECHR, both the Employment Tribunal and the Employment Appeal Tribunal held that his private life was not in question. Mr Pay's activities 'had been publicised on the website of Roissy of which he was a director and [...] he was present in bars and clubs, to which the public was admitted, promoting the interests of Roissy in [Bondage, Domination and Sado-Masochism]'. ${ }^{28}$

Mr Pay's activities were not private, his right to private life had not been breached, and so his dismissal was fair.

\footnotetext{
25 It provides that '[t]he enjoyment of the rights and freedoms set forth in this Convention shall be secured without discrimination on any ground such as sex, race, colour, language, religion, political or other opinion, national or social origin, association with a national minority, property, birth or other status'.

26 See, for instance, Inze v Austria, App. No. 8695/79, Judgment of 28 October 1987, [36].

$27 X \mathrm{v} Y,[52]$.

28 Pay, [36].
} 


\section{SPACE}

In $X \mathrm{v} Y$, Brooke LJ opined that '[r] eally live human rights issues may well be lurking in the background of this particular case'. ${ }^{29}$ Yet worryingly these questions were not tackled, mainly due to a misconception of privacy, which the present section attempts to expose. The central criterion articulated by courts and tribunals in rejecting the claims of Mr X and Mr Pay was spatial. The applicants' conduct did not occur in private - at home or some other secluded, private location - but in public: in a public lavatory, in clubs, and on the internet. The resulting dismissal, accordingly, did not constitute a violation of private life. Not only did it not breach article 8 ; it did not even fall within the ambit of the provision for the purposes of article 14 that prohibits discrimination, a construction which in Strasbourg case law frequently leads to an expansive interpretation of other Convention provisions read in conjunction with it. ${ }^{30}$

But was it correctly held that there is a bright spatial line that divides public from private for present purposes? Was the right to privacy affected in Mr X's case, when dismissal stemmed from his sex life, usually cherished as a most intimate aspect of one's personhood, or was emphasis rightly placed on the location where the behaviour in question occurred in the determination of whether it should be protected as private? Were Mr Pay's activities outside the scope of article 8, for the sole reason that they took place in a non-secluded location, namely on the internet, in bars and clubs?

My position is that private location was erroneously presented as a decisive factor when drawing the boundaries of the right to private life and, more generally, that the spatial criterion used by courts was flawed - an argument that can be illustrated by several examples. But before pursuing that line of argument, one further concern ought to be raised. In $X \mathrm{v} Y$, the Employment Appeal Tribunal stated that the applicant's activity "was a "transitory sexual encounter" between two strangers in a public lavatory and was not covered by the right to respect for private life'. ${ }^{31}$ Yet this approach is questionable, for it is likely that anyone who has used a lavatory in a café or a restaurant will be surprised to hear that the location and, as it follows from the court's reasoning, the activities that take place therein, are not protected activities of their private life. Individuals have an expectation of privacy when they use a lavatory, which is very reasonable, a consideration that makes it difficult to agree with the contention that $\mathrm{Mr}$ X's activities took place in public.

Leaving the question of the café's lavatory aside, I wish to test whether location is the correct criterion to use in the public/private divide by exploring activities in public that may still be protected as aspects of the right to private life.

\footnotetext{
${ }^{29} X_{\mathrm{v}} Y,[84]$.

30 See, for instance, Sidabras and Driautas v Lithuania, App. Nos. 55480/00, 59330/00, Judgment of 27 July 2004, where a right to work was found to fall within the ambit of the right to private life. For an analysis, see V. Mantouvalou, 'Work and Private Life: Sidabras and Driautas v Lithuania' (2005) 30 ELR 573.

31 Xv $Y,[23]$.
} 
Consider the following examples: firstly, two people kissing passionately in Trafalgar Square; and, secondly, a man reading a newspaper on the bus. The kiss may be protected as private should a photographer capture the moment and use it to illustrate a magazine article on unfaithful spouses. The reading of a newspaper will be protected as private should state authorities collect this information so as to classify citizens according to their political beliefs. At first glance, in other words, and only by appealing to our basic intuitions, the reasoning of the courts and tribunals suffers from a weakness.

The ECtHR has recently pondered the question of location and privacy. Peck $\mathrm{v} U K$ established that public location does not preclude protection under article 8.32 Having attempted to commit suicide, Mr Peck was caught in CCTV cameras. The footage was provided by public authorities to newspapers and TV programmes which transmitted recognisable images of the applicant. The Court rejected the view that these images remain outside the scope of article 8 , since they were captured in public, placing its attention on the question whether Mr Peck could have foreseen that his images would have been used in this way. ${ }^{33}$ It found a breach of the right to private life. A further attempt to tackle the issue was $V$ on Hannover v Germany. ${ }^{34}$ Caroline Von Hannover, the Princess of Monaco, alleged that publication in the tabloid press of her photographs, taken while she was in public - in restaurants, on holidays with family and friends, shopping at the market - constituted a violation of her private life. The ECtHR decisively rejected the dominant view in German jurisprudence that privacy is to be equated to seclusion: 'the criterion of spatial isolation, although apposite in theory, is in reality too vague and difficult for the person concerned to determine in advance'. ${ }^{35}$ Germany violated the right to private life.

On the other side of the coin, the veil of privacy does not hinder state intervention with domestic affairs traditionally classified as private. Whilst in the past the public/private dichotomy based upon location as its main parameter was mainly challenged by scholars looking at issues of domestic violence and marital rape, ${ }^{36}$ today a similar position is adopted in UK law. Both acts constitute criminal offences, despite their private location, and the example of the criminalisation of possession of child pornography at home provides a further example to that end. ${ }^{37}$

\footnotetext{
32 Peck v UK, App. No. 44647/98, Judgment of 28 January 2003.

33 ibid, [62].

${ }^{34}$ Von Hannover v Germany, App. No. 59320/00, Judgment of 24 June 2004.

$35 \mathrm{ibid}$, [75]. For a similar position adopted by the House of Lords on the publication of the applicant's photo taken when she was in public, see Campbell v MGN Limited, [2004] UKHL 22.

36 There is much literature by feminist scholars on the public/private dichotomy. See, for instance, the collection Women's rights: The Public/Private Dichotomy, J. Motiejunaite (ed.), (New York: International Debate Education Association, 2005). See also B. Rossler, 'Gender and Privacy: A Critique of the Liberal Tradition' in B. Rossler (ed.), Privacies - Pbilosophical Evaluations (Stanford, California: Stanford University Press, 2004) 52.

37 On marital rape, see, $R$ v R [1992] AC 599 House of Lords. On domestic violence, see the Domestic Violence, Crime and Victims Act 2004. On possession of child pornography see the Criminal Justice Act 1988, s 160.
} 
It emerges that the spatial element as a determinative factor of the public/private division leads to an inadequate conceptualisation of privacy both when appeal is made to our basic intuitions and when attention turns to human rights and criminal law. Additional complexities come to the surface when focus shifts to the employment context. Mere location of an act cannot capture the complexity of the material scope of the right to private life or the subtleties that the employment relation poses to the public/private dichotomy. ${ }^{38}$ The workplace is not necessarily distinguishable from home, and yet classifying it as public is probably an unsatisfactory solution. Let us take the academic job, as an example. Conducting research from home is relatively common, and the employer's expectation to respond to emails at some point during working hours while away from the workplace does not necessarily infringe privacy. On the other hand, the opposite would probably be true if the employer imposed a duty to respond to emails outside working hours. Live-in domestic workers further exemplify how the boundaries between home as a location for all private activities, and the workplace as public, is blurred. The domestic worker provides her services at the employer's home, while also frequently spending her leisure time there. This is to say that the private, secluded character of the workplace does not imply that abuse of her labour rights is not of state concern; the employer's conduct is not shielded by some supposed protection of the right to private life..$^{39}$

And again looking at the other side of the matter, the ECtHR in an oft-cited passage from the Niemietz v Germany case ${ }^{40}$ took a generous view of the right to privacy, holding that in principle business premises may be protected under article 8 , although the workplace would at first glance not be classified as private by invoking the spatial criterion. The Court stated that ' $\mathrm{r}]$ espect for private life must ... comprise to a certain degree the right to establish and develop relationships with other human beings', and went on to explain that

[t]here appears [...] to be no reason of principle why this understanding of the notion of 'private life' should be taken to exclude activities of a professional or business nature since it is, after all, in the course of their working lives that the majority of people have a significant, if not the greatest, opportunity of developing relationships with the outside world. ${ }^{41}$

All the above indicates that private life is not to be restrictively interpreted as encompassing one's home and family circle; the right to privacy does not merely

\footnotetext{
${ }^{38}$ See G.S. Morris, 'The Human Rights Act and the Public/Private Divide in Employment Law', (1998) 27 ILJ 293.

39 See Siliadin v France, App. No. 73316/01, Judgment of 26 July 2005. For an analysis see V. Mantouvalou, 'Servitude and Forced Labour in the 21st Century: The Human Rights of Domestic Workers' (2006) 35 ILJ 395. On domestic labour see also G. Mundlak, 'Recommodifying Time: Working Conditions of "Live-in" Domestic Workers', in J. Conaghan, K. Rittich (eds.), Labour Law, Work and Family (Oxford: Oxford University Press, 2005) 125.

40 Niemietz v Germany, App. No. 13710/88, Judgment of 16 December 1992.

41 ibid, [44].
} 
encapsulate activities that take place in a secluded, inaccessible location. The spatial criterion is flawed, for it fails to capture the subtleties of the distinction between public and private for the purposes of article 8 of the Convention. It is also insufficiently attentive to the complexities of the interaction between work and private life, and leads to incomplete protection of the right to private life in dismissal.

\section{THE VALUE OF PRIVACY}

Courts and tribunals relied on a disappointingly narrow spatial criterion when exploring the legality of dismissal read in light of the right to private life, which fails to conceptualise correctly the right to private life in employment, while also being remarkably unsuccessful in capturing the importance of privacy to the individual. A fresh interpretation of article 8 is essential. But before embarking on this task, an exploration of key literature on privacy is probably necessary.

To be sure, this section does not intend to provide a comprehensive account of the main literature on privacy, but rather to identify certain themes that can shed light on what proves to be a far from straightforward concept. ${ }^{42}$ Few authors contest the importance of a right to privacy. ${ }^{43}$ For an individual living in isolation privacy is, of course, hardly significant, since the possibility of external interference with her private affairs is remote. Yet for most people living in communities privacy is valuable. People may belong to multiple associations - their country, their city or town, their neighbourhood, their workplace. And while they may enjoy sharing moments with their friends, family, colleagues, partners, fellow citizens, still they do not wish each one of the members of their family, their fellow citizens, colleagues, friends, to know of all their actions and thoughts. They wish to keep some of them private.

The protection of the right to privacy has been of special concern in modern societies, taking on special significance over the last few decades in particular. Technological advancements make intrusions upon private life particularly sophisticated; video surveillance in the streets, on public transport, in restaurants and cafés makes a person visible virtually every moment of her life. The media has the power to gather and disseminate to the public details of people's intimate life. The internet, where information is easily accessible by anyone who has access to a

\footnotetext{
42 For an introductory discussion of key literature, see F.D. Schoeman, 'Privacy: Philosophical Dimensions of the Literature' in F.D. Schoeman (ed.), Philosophical Dimensions of Privacy - An Anthology (Cambridge: Cambridge University Press, 1984) 1. The collection will be hereinafter cited as Philosophical Dimensions.

${ }^{43}$ For a reductionist argument that suggests that privacy can be broken down in various other rights, see J.J. Thomson, 'The Right to Privacy', in the same volume, 272. For a response to Thomson, see T. Scanlon, 'Thomson on Privacy' (1975) 4 Philosophy and Public Affairs 295, and R. Gavison, 'Privacy and the Limits of Law', in Pbilosophical Dimensions, 346.
} 
computer and a telephone line, is another source of concern. Gathering information is easy; disseminating it can be quick and costless.

Privacy is 'contextually dependent'. ${ }^{44}$ Its scope may vary and change over time and geographical area. A mental health problem affecting an individual, for instance, would have perhaps been deemed an embarrassing family secret in the past. Today it may be shared with others in a community, with a view to seek support and offer a solution to the problem. Pre-marital sexual relationships, once disapproved of and kept secret from society, are not seen as necessarily private in many parts of the modern world, in big cities in particular. But in smaller rural communities, they may still be a taboo.

The scope of privacy does not only vary over time and geographical area but also from one relationship to the other. Thoughts that someone deems private in her relation with her neighbour are not necessarily private between her and a friend; what she keeps secret from her teacher may be shared with her family; issues that are kept private between two friends may be shared between two partners. Gavison stated that 'the typical privacy claim is not a claim for noninterference by the state at all. It is a claim for state interference in the form of legal protection against other individuals'. ${ }^{45}$ Yet not all intrusions of privacy demand the protection of the law. Reading a person's diary by her parents raises privacy issues, and so does listening to a friend's telephone conversations; opening prisoners' correspondence by prison guards also infringes their privacy; so does police monitoring of a person's activities in her bedroom. Not all of these instances of infringement of privacy are of concern to the state though. They do not all impose negative - in case of infringement by state authorities - or positive - in case of infringement by individuals - duties.

The reasons why we value privacy will determine the scope of the right. Privacy may promote human dignity. Individuals wish to perform some activities in private, for it would be deeply embarrassing and undignified to be forced to engage in certain conduct in public. Moreover, privacy leads to freedom of action. ${ }^{46}$ Individuals may have views and preferences that are controversial and unpopular, but do not necessarily wish to confront and challenge societal beliefs. Keeping their views and actions private enables them to pursue their aims unobstructed. Privacy can further be seen as a necessary precondition for individual autonomy and human flourishing. Constant exposure to public observation would hinder concentration and reflection; human thought would not advance without conditions of privacy, scientific and artistic creativity would become illusory.

Privacy is essential for interpersonal relations. Charles Fried in his seminal piece on 'Privacy'47 argued that privacy creates the 'moral capital'48 for love,

${ }^{44}$ F.D. Schoeman, 'Privacy and Intimate Information', in Philosophical Dimensions, 403, 404.

45 Gavison, n 43 above 357.

46 ibid 363.

47 C. Fried, 'Privacy', in Philosophical Dimensions, 203, hereinafter cited as 'Privacy'. See also C. Fried, An Anatomy of Values (Cambridge, Massachusetts: Harvard University Press, 1970), chapter IX, hereinafter 
friendship and trust to flourish, for by enjoying privacy, individuals are able to reveal some information to certain people, while they conceal it from others. The inability to select to whom they will disclose this information would have a harmful effect on these relationships, and individual integrity would be threatened, for ' $[t]$ o respect, love, trust, or feel affection for others, and to regard ourselves as the objects of love, trust, and affection is at the heart of our notion of ourselves as persons among persons, and privacy is the necessary atmosphere for these attitudes and actions, as oxygen is for combustion'.49

Privacy is important for sexual intimacy. .50 An individual's sex life may not necessarily involve emotional attachment, but her sexual relationships may be equally valuable to her choices, her well-being and her autonomy. For most people, conditions of privacy are necessary for sexual intercourse, for they cannot relax without privacy, and relaxation is crucial in these situations. Relations of sexual intimacy would be affected if privacy was not possible. The ECtHR recognised the importance of sex life for private life in Dudgeon $\mathrm{v} U K K^{51}$ The case involved legislation that banned homosexual activities between consenting adults, involving a 'most intimate aspect of private life', ${ }^{2}$ and the Court ruled that public authorities can only interfere with it if they have particularly serious reasons. They were, hence, found to violate the Convention. A similar position was adopted by the US Supreme Court in Lawrence $\mathrm{v}$ Texas, ${ }^{53}$ which underlined the importance of sexuality for individual autonomy.

The reasons we value privacy are of utmost importance. And yet, the spatial element that courts articulated in the cases of $\mathrm{MrX}$ and Mr Pay was an insufficient criterion in sketching the material scope of article 8 of the Convention. Can we advance a fresh approach?

\section{WORKPLACE PRIVACY CONTEXTUALISED}

Academic literature suggests that privacy is contextually dependent, which implies that in exploring the right to privacy and its infringements, the character of the relationship where the complaint arises is of fundamental significance. Courts' and

cited as Anatomy. For further analysis of Fried's argument see J. Rachels, 'Why Privacy is Important', in Philosophical Dimensions, 290. For criticism of this view see J.H. Reiman, 'Privacy, Intimacy, Personhood' in Philosophical Dimensions, 300.

${ }^{48}$ Fried, 'Privacy', 211.

${ }^{49}$ Fried, Anatomy, 140

50 Gavison, n 43 above, 363. For an analysis of this view see R.S. Gerstein, 'Intimacy and Privacy', in Philosophical Dimensions, 265.

51 Dudgeon v UK, App. No. 7525/76, Judgment of 22 October 1981.

52 ibid, [52]. See also ADT v UK, App. No. 35765/97, Judgment of 31 July 2000. Cf. Laskey, Jaggard and Brown v UK, App. Nos. 21627/93, 21826/93, 21974/93, Judgment of 19 February 1997. For an overview of the relevant case law, see C. Ovey, R.C.A. White, Jacobs \& White The European Convention on Human Rights (Oxford: Oxford University Press, 4th ed, 2004) 270 ff.

${ }^{53}$ Lanrence v Texas, 539 US 558 (2003). 
tribunals' conceptualisation of privacy in employment, though, was not entirely satisfactory, as it emerged from the previous section, primarily because the content of the right was not thoroughly thought through in the context of the employment relation.

The decisions in $X_{v} Y$ and Pay were criticised by labour law scholars. Collins, for instance, argued that the main problem in these cases is that courts and tribunals took a view of privacy which suits the state/individual relationship, 54 and observed that 'what is missing from these judgments is recognition that the context of the employment relation requires a different conception of the public/private distinction'. ${ }^{55}$ How could this position be refined? Recent case law suggests that human rights law does not equate privacy to seclusion; it does not endorse location as conclusive when examining what should be protected as private against state interference. ${ }^{56}$ A possible suggestion that the line between public and private should be redrawn using location only as a determinative factor, in the sense that everything that takes place outside the workplace should be deemed private, could be equally problematic as the approach adopted in Pay and $X \mathrm{v} Y$. Can the public/private divide be drawn using some other criterion in the employment context? The main concern, this article suggests, is that in these cases judicial reasoning did not pay sufficient attention to the importance of the protection of private life against employer interference. In what follows, I hope to address this, by suggesting an alternative understanding of the value of privacy that is more suitable to the employment relation. I endeavour to construe the content of the right against employer (rather than state) interference.

Our separate exploration of the right to privacy in the employment context does not imply that the notion of privacy enshrines distinct values in different contexts. And yet while the values reflected are similar, the addressees of the claim and the power that they exercise upon the individual differ. In human rights law, the right to private life primarily shields individuals from illegitimate intrusion by state authorities; in labour law the protection turns against the employer. Labour law, like the law of human rights, encapsulates a belief that individuals should be treated as equals. The commonly expressed concern about the inequality of bargaining power between the employer and the employee rests in the heart of labour law, 57 and an equivalent concern about the inequality between powerful state authorities and the individual rests in the heart of human rights law. This also provides a reason why one should be open to rights-based arguments when looking at fairness in dismissal. In all contexts, privacy promotes individual goods, such as human dignity and autonomy, whilst also creating the necessary conditions for various forms of social interaction to flourish.

\footnotetext{
54 Collins, n 5 above 623.

55 ibid, 623-624. See also H. Collins, 'Utility and Rights in Common Law Reasoning: Rebalancing Private Law Through Constitutionalization', LSE Law, Society and Economy Working Papers 6/2007, 18-20 in particular.

56 See Peck and Von Hannover, discussed in text accompanying n 32-35 above.

57 P. Davies and M. Freedland, Kahn-Freund's Labour and the Law (London: Stevens, 3rd ed, 1983$) 18$.
} 
Before elaborating more on the scope of privacy in the employment context, I ought to make three sets of observations, with a view to illustrating the potential danger posed by the employer's power to interfere with the employee's private life, and to identify several effects of the intrusive conduct. The first set of observations involves the idea of domination, a concern inextricably linked to the character of the employment relation; the second touches upon the value of the protection of privacy for the work/life balance, a common discourse in employment law; and the third relates to employees' interpersonal relations.

\section{DOMINATION}

The contract of employment incorporates the obligation of the employee to perform certain duties; the employer has an obligation to remunerate her for the performance of these duties. The economic dependence of the employee on the employer generates an imbalance of power. The employment contract was therefore presented by Kahn-Freund as 'an act of submission', the employment relation as one of 'subordination'. ${ }^{58}$ The employer may impose duties unrelated to the performance of contractual obligations - an unfair situation in which inadequate regulation can lead to a relationship that can fairly be described as one of domination. Philip Pettit analysed domination as a relationship with three aspects. A person dominates another if

'1. they have the capacity to interfere

2. on an arbitrary basis

3. in certain choices that the other person is in a position to make'.59

Pettit's analysis is neither limited to the employment relation nor to infringements of privacy, and yet he provides us with useful insights by claiming that the employer has the capacity to interfere arbitrarily with the employee's freedom, if he can fire him 'as whim inclines him and hardly suffer embarrassment for doing so'. 60

To be sure, there are different degrees of domination, with no comparison between a $19^{\text {th }}$ century slave and a modern day employee. And still, the idea that the employer may interfere with the worker's liberty and her choices not only within the workplace and during working time, but also outside work, is inimical to a relationship of equals. Abuse of the employer's position and the relation of economic dependence, and interference with the employee's private time beyond what is necessary for the performance of the contractual duties, in a manner that can impact significantly on her liberty to make her life choices as an autonomous

\footnotetext{
58 ibid.

59 P. Pettit, Republicanism: A Theory of Freedom and Government (Oxford: Oxford University Press, 1999) 52. For further analysis of the idea of domination, see Political Exclusion and Domination, in M.S. Williams and S. Macedo (eds.), Nomos XLVI (New York: New York University Press, 2005).

${ }^{60}$ Pettit, n 59 above, 57.
} 
agent, exemplifies how domination can exist in a modern-day employment relation.

The power to dominate runs contrary to the most fundamental values underlying human rights and employment law, providing a compelling reason for state intervention. A floor of fundamental rights in the workplace, including the right to private life, may usefully address the imbalance of power and the risk of domination. To further illustrate the effects of intrusion, the sections that follow discuss the effects of employer interference with privacy in two areas.

\section{Privacy and the Work/Life BalanCe}

I suggest that a first consideration to bear in mind when looking at privacy in the employment context concerns the work/life balance. In employment law, academic literature presents the question of a balanced division between work and life as a fundamental one. ${ }^{61}$ The debate involves in essence employees' time, with dimensions of the discussion touching upon a living wage and flexible working hours. Often examining the conflict between work and family responsibilities, maternity and paternity leave, several scholars focus on the increased pressure to reconcile family duties with employment. ${ }^{62}$ The work/life balance has become topical in the context of the European Union, as part of the promotion of flexibility in the employment contract. ${ }^{63}$

The work/life balance debate is essentially about having private time. Yet it should not be necessarily analysed from this perspective narrowly, for it can also involve control over the quality of private time. In their leisure time, when they are not under a duty to follow the employer's instructions, most people engage in activities that they consider fulfilling. They are free to lead their life as they wish; they can rest, go to concerts, read novels, spend time with friends and partners, travel, go to artistic exhibitions. The imposition of a duty to act in a certain way or to refrain from engaging in certain conduct in a person's private time can be detrimental to this freedom. In the relationship between the state and the individual, the imposition of such prohibitions can give rise to a number of human rights issues. It can breach freedom of expression, the right to private life, freedom of religion. In the context of employment, being watchful and alert when engaging in leisure activities, and being fearful that they may impact on the retention of employment, may be damaging to the delicate work/life balance.

\footnotetext{
${ }^{61}$ For an overview of the key issues see H. Collins, K.D. Ewing, A. McColgan, Labour Law: Texts and Materials, (Oxford: Hart, 2nd ed, 2005), Chapter 4. See also the collection Labour Law, Work and Family, n 39 above. For an analysis of the issue in Canada, see H. Arthurs, 'Fairness at Work - Federal Labour Standards for the $21^{\text {st }}$ Century', Federal Labour Standards Review, 2006, Chapter 7, and in France see J-E. Ray, 'Temps Professionnel et Temps Personnels', Droit Social, n 2 above, 58 ff.

${ }^{62}$ See, for instance, 'The Work and Families Act 2006: Legislation to Improve Choice and Flexibility?' (2006) 3 ILJ 272 and E. Caracciolo di Torella, New Labour, New Dads - The Impact of Family Friendly Legislation on Fathers' (2007) 36 ILJ 318.

${ }^{63}$ See H. Collins, 'The Right to Flexibility', in Labour Law, Work and Family, n 39 above, 99, and S. Fredman, 'Women at Work: the Broken Promise of Flexicurity' (2004) 33 ILJ 299.
} 
Protection of the employee's activities after work creates a better division between work and life, while a sharp separation is essential to enhance the quality of private time and promote the employee's freedom to live as an autonomous agent.

\section{PrivaCy AND INTERPERSONAL RELATIONS}

And yet the impact on the work/life balance is not the sole consideration when examining employer's interference with private life. A second area, where the effect of such interference is identifiable, involves social interaction. Fried argued that privacy is an essential condition for relations of love, friendship and trust, as explained earlier. In the employment context, by paying special attention to the legal protection of life after work, we create the conditions for development of such meaningful relationships. Control over information that an employee will reveal and other that she will conceal from her employer creates the moral capital to be spent with her loved ones. Pressure to disclose indiscriminately what she wishes to keep private may deprive her of the capacity to maintain relations of the highest moral value.

In addition, intrusion upon the employee's private life may impair all relations of sexual intimacy for a variety of reasons. Societal beliefs about morality change and people are often prejudiced on sex-related matters. An employer may dismiss the employee because it has a view about morality that conflicts with hers, it disapproves of her sex life, or deems her choices unconventional or immoral and hence incompatible with business interests. ${ }^{64}$ Yet discipline or dismissal for such reasons risks leading to an indirect imposition of the employer's personal morality upon the employee. ${ }^{65}$ It can damage individual choice and the liberty to have sexual relationships that fall short of love, but which may be highly valued as essential for a person's well-being.

There is a further effect of invasions of privacy and sex-related matters, which we need to bear in mind here. Individuals tend to keep their sex life private for reasons that have been touched upon earlier in this article. Dismissal, of course, always affects the employee's self-esteem, having an impact on every aspect of her life. In case of dismissal for non-intimate matters, though - dressing habits, for example - the individual can share her feelings with her family and friends, she can openly blame the employer who disagreed with her life-style, she will probably not hesitate to criticise and challenge the decision. The individual who is dismissed for her sex life, on the other hand, will be reluctant to share her outrage with others, for the embarrassment that she will experience in having to reveal her sexual preferences will make any such prospect deeply disturbing. The

${ }^{64}$ For a discussion of restrictions on sexual relationships in the workplace see L. Clarke, 'Sexual Relationships and Sexual Conduct in the Workplace' (2006) 26 Legal Studies 347.

${ }^{65}$ For the view that human rights embody a principle that no-one should be deprived of a liberty on the basis that others regard her plan of life as immoral, see G. Letsas, $A$ Theory of Interpretation of the European Convention on Human Rights (Oxford: Oxford University Press, 2007) 117. 
pain provoked and the stigma attached to the person dismissed because of her 'unacceptable' preferences in her sex life, her sexual relations and activities, provides an additional reason why privacy should be valued in case of dismissal for reasons that involve sexual intimacy.

Privacy should be cherished for a variety of reasons, which I have attempted to present. It is highly valued for its role in the exercise of individual autonomy and for a satisfactory division between work and life. It constitutes a precondition of social relationships of love, friendship and trust and for other intimate sexual relationships that a person may treasure, but the employer may resent. Inadequate protection of privacy may lead to a relation of domination. The employer has the power to restrict the employee's freedom arbitrarily, by making illegitimate use of its authority stemming from the relationship of economic dependence. Redrawing the boundaries between public and private using location as a central factor would not sufficiently address our concerns, for describing life in the workplace as public and all that occurs outside it as private may only superficially answer the normative problem of privacy in dismissal. At a deeper level, the problem would remain, because the employee would still be vulnerable to illegitimate intrusions while at work, while the employer might remain powerless if the employee acted in a manner inconsistent with her contractual duties after work. But how could the right be reconceptualised in the employment context?

\section{WORKPLACE PRIVACY RECONCEPTUALISED}

The previous section attempted to identify the normative problem of the protection of private life in dismissal, and proposed that it is necessary to contextualise it and explore its value in the employment relationship. Can we look at article 8 afresh, and re-interpret its content in a manner that will suit the idea of private life, focusing in particular on life after work, which cases such as $X \mathrm{v} Y$ and Pay examined? Freedland expressed scepticism about the conception of privacy embraced by the court in $X \mathrm{v} Y$, as it was based upon the idea of secrecy. He suggested that the real point was that 'the facts were viewed through the optic of privacy as a claim to secrecy, and the more fundamental aspects of respect for private life were marginalised as secondary and subordinate considerations', ${ }^{66}$ and expressed 'concern about the future of direction and methodology of regulation of workers' privacy in English employment law'. ${ }^{67}$ In this sense, and while in the present article the terms 'privacy' and 'private life' have been used interchangeably, the broader notion of a 'right to private life' may better suit our purposes, when referring to life after work.

${ }^{66}$ Freedland, n 2 above, 151.

67 ibid. 


\section{SECRECY OR CONTROL?}

People engaging in activities while in public space are often visible to others, and still their activities do not necessarily cease to be private, as shown earlier, for the value of privacy reaches beyond conduct in seclusion and transcends the spatial element on which courts and tribunals have based their reasoning. Fried argued that the idea of privacy as a claim to secrecy, 'to limiting the knowledge of others about oneself, ${ }^{68}$ needs to be subject to refinement. 'It is not true, for instance, that the less that is known about us the more privacy we have. Privacy is not simply an absence of information about us in the minds of others; rather it is the control we have over information about ourselves. ${ }^{6} 9$

Several scholars have endorsed the idea of control as a constitutive element of the concept of privacy. ${ }^{70}$ Schoeman argued that privacy restricts the control of others over our lives, ${ }^{71}$ and Rachels suggested that 'because our ability to control who has access to us, and who knows what about us, allows us to maintain the variety of relationships with other people that we want to have, it is $[\ldots]$ one of the most important reasons why we value privacy'.72 Not all losses of privacy are, in this sense, viewed as offensive. ${ }^{73}$ A loss of privacy is not offensive when someone voluntarily reveals a secret to a friend or willingly shares information with her employer, although it may become offensive when it occurs beyond a person's control, without her knowledge or her consent. The view that privacy is about informational autonomy and control finds further support in recent domestic case law. In Douglas v Hello! ${ }^{74}$ for instance, the right to privacy was held to protect the applicants' choice to publish their wedding photos in the magazine Hello! rather than one of its competitors. At the same time it follows that loss of privacy may become offensive, if the private information voluntarily revealed is then used for a purpose other than the one agreed. Looking at the question of prior publicity, Lindsay J was sceptical, arguing that ' $[\mathrm{t}$ ] o hold that those who have sought any publicity lose all protection would be to repeal Article 8's application to very many of those who are most likely to need it'. ${ }^{75}$

Fried contended that

[t]he concept of privacy requires [...] a sense of control and a justified, acknowledged power to control aspects of one's environment. In most developed societies the only way to give a person the full measure of both the sense and the fact of control is to give him a legal title to control. A legal right

\footnotetext{
${ }^{68}$ Fried, 'Privacy', 209.

${ }^{69}$ ibid.

70 See A.F. Westin, Privacy and Freedom, (New York: Atheneum, 1967) 7, Reiman, n 47 above, 314, and Rachels, n 47 above, 292, S. Benn, 'Privacy, Freedom, and Respect for Persons' in J.R. Pennock, J.W. Chapman (eds.), Privacy, Nomos XIII (New York: Atherton Press, 1971) 1. But see Gavison, n 43 above.

${ }^{71}$ F.D. Schoeman, Privacy and Social Freedom (Cambridge: Cambridge University Press, 1992) 7.

72 Rachels, $n 47$ above, 295.

${ }^{73}$ H. Gross, 'Privacy and Autonomy', in Privacy-Nomos XIII, n 70 above, 169 at 171.

74 Douglas v Hello! [2003] EWHC 786.

75 ibid, [120].
} 
to control is control which is the least open to question and argument, it is the kind of control we are most serious about. ${ }^{76}$

Let us again turn to English employment law. Is there such a right to control private information? Prior to the incorporation of the HRA into domestic law, the protection of privacy was wanting. The employer's power to dominate the employee by imposing on her duties to behave in a certain way or abstain from activities after work, even when these had no bearing on the contractual relation, was unrestricted. Successfully challenging dismissal that resulted from such conduct was an almost impossible task. With the incorporation of the Convention into domestic law, though, a legal right to control information was introduced - a right which (if appropriately interpreted) may open the route to a more just approach to dismissal.

Freedland predicted that the main focus of English employment law when looking at the right to privacy will be on the idea of derogability by the employment contract. ${ }^{77}$ Autonomous individuals can opt to reveal information about themselves to others; they are free to discuss with their friends or acquaintances about their health, their sex life, their job, and of course restricting individual autonomy is not one of the purposes of human rights law. Human rights law appreciates that individuals are responsible agents, capable of choosing how to exercise their liberties. Derogability from fundamental rights by the employment contract in particular is a complex question, with which academic literature has grappled. ${ }^{78}$ And although it may often play a significant role in workplace privacy debates, the $X \vee Y$ and the Pay cases exemplify how issues of protection of private life against employer interference will occasionally not revolve around derogability. Information on Mr Pay's activities was in the public domain, and hence obtainable by his employer, and Mr X's name was included in a list of offenders to which the employer had access. Neither of them had agreed to derogate from their rights. Notwithstanding the availability of this information in the public domain, the applicants could be granted a legal right to control it if invoked by the employer as a reason for dismissal.

The crux of the argument this far is that dismissal for reasons that have no bearing on the performance of contractual duties in employment may lead to an unfair relationship of domination, and the right to privacy can provide a useful tool in addressing the imbalance of power and the resulting injustice. Understood not as a right to act in seclusion, but as a right to control information unrelated to the duties of the employment contract when invoked by the employer as reasons

\footnotetext{
76 Fried, Anatomy, 152.

${ }^{77}$ Freedland, n 2 above, 152.

78 See G.S. Morris, 'Fundamental Rights: Exclusion by Agreement', (2001) 30 ILJ 49 and Craig, n 2 above, 156. See also H. Oliver, 'Email and Internet Monitoring in the Workplace: Information Privacy and Contracting-Out', (2002) 31 ILJ 321. For further theoretical analysis of the matter, see S. Leader, 'Freedom and Futures: Personal Priorities, Institutional Demands and Freedom of Religion', (2007) 70 MLR 713. Consent to waive fundamental rights have not remained unchallenged before the ECtHR. See Mantouvalou, n 39 above, 410 .
} 
for dismissal, the right to privacy can provide the appropriate remedy that will protect the employee against domination. And while it is important to appreciate this, it is my position that we can introduce one further element in our analysis of life after work - privacy and dismissal.

\section{ZONES OF PRIVACY: TIME}

In literature that explores privacy, it is contended that its protection requires control over well-defined zones, where a person will not fear offensive observation and will not suffer consequences because of interference by others. ${ }^{79}$ Seclusion did not prove to be an appropriate criterion in defining zones of privacy; it has been rejected in general human rights law, and is insufficiently sensitive to the particularities of the employment relation. In what follows, I wish to propose that an alternative temporal - rather than spatial - dimension can elucidate the concept of privacy against employer interference. Always bearing in mind the complexities of the conflicting interests at stake, ${ }^{80} \mathrm{I}$ argue that life after work is covered by a strong claim to privacy, in which the scope for exceptions is very narrow.

Dismissal because of activities after work may satisfy the test of fairness only if the employee's behaviour has a direct impact or a high likelihood of such impact on the performance of her contractual duties, while an existing effect or a bigh likelihood of such effect on the employer's reputation may also be a weighty consideration. The main point here is that a remote and marginal danger does not suffice. It ought to be stressed at this stage, that the temporal element, which I introduced in this section, is a heuristic device; what I suggest is that it may constitute a useful criterion when drawing a zone of privacy against employer intrusion. A variety of reasons analysed earlier support this position, with the idea of the work/life balance constituting one of the most basic ones. In principle, private life covers all aspects of the employee's life outside the workplace and working time as a starting point, and employer interference with it requires strict scrutiny, for it is improbable that these activities will be related to the contractual duties and have an impact on workplace performance.

To anticipate an objection at this stage, a temporal distinction does not suggest that life after work is purely private in the common understanding of the term and in contexts other than the employment relation. Individuals spend their leisure time engaging in a wide range of activities: they may be sportspersons, art lovers, part-time students, and their life choices often involve social interaction in public space and engagement with others in a community. Yet, in the employment context and for the purposes of the protection against unfair dismissal, what a person does in her leisure time is unlikely to have a connection with the

\footnotetext{
${ }^{79}$ Scanlon, $\mathrm{n} 43$ above, 317.

${ }^{80}$ For an analysis of some general guidelines on claims against privacy, see R. Gavison, Information Control: Availability and Exclusion' in S.I. Benn \& G.F. Gaus (eds.), Public and Private in Social Life, (New York: St. Martin's Press, 1983) 113.
} 
performance of contractual duties, making the legality of discipline or dismissal for such behaviour questionable. I should explain, in addition, that the temporal division does not imply that anything that occurs within the workplace or working hours cannot be shielded by the veil of privacy. The division of time is not absolute and the present article does not suggest that the employer can freely dismiss the employee for any activity within the workplace and working time. ${ }^{81}$ All that I hope to show is that the temporal element operates as a presumption of privacy against dismissal for breaching the right to control information.

To be sure, the position that a temporal distinction may usefully serve present purposes is hardly groundbreaking, for it has been endorsed both in national and international fora. French law contains a sharp temporal separation between work and life. ${ }^{82}$ Jurisprudence of the Cour de Cassation suggests that life at work and personal life constitute two distinct spheres, while at the same time recognising that in certain circumstances there is a degree of interaction. The dominant position is that disciplinary action and dismissal may not be imposed for activities away from work, unless they impede the employee from performing her job or lead to some other serious and identifiable harm to business. ${ }^{83}$ The cases Painsecq v Association Fraternite Saint-Pie X, ${ }^{84}$ where the Cour de Cassation ruled that termination of employment on the grounds of the applicant's homosexuality was unfair, and Mazurait v AIMT, ${ }^{85}$ where dismissal of a medical secretary because she was a tarot reader in her spare time was ruled unfair, both illustrate the point. Article 8 of the Convention is generally interpreted generously. Its material scope was examined in a case of an employee who challenged the imposition of a duty by the employer to change his place of residence and move to a new location. ${ }^{86}$ And though such 'mobility clauses' are not generally illegitimate, in the instant case the clause was found to restrict disproportionately the right to private life under the ECHR.

The example of France is not unique. In Germany, in a case similar to Pay, the dismissal of an elementary school teacher who worked as an exotic dancer at a local club, was held to be unlawful, mainly because the distance between the club and the school was seventy kilometers, and the teacher's activities were not known

${ }^{81}$ This issue has been explored in academic literature mentioned in $\mathrm{n} 2$ above, and has been addressed by the ECtHR in Halford v UK, App. No. 20605/92, Judgment of 25 June 1997, and Copland v UK, App. No. 62617/00, Judgment of 3 April 2007.

82 For academic analysis and examples from the case law, see the (2004) Droit Social, entitled 'Vie Professionnelle et Vie Personnelle'. See, in particular, P. Waquet, 'La Vie Personnelle du Salarié', 23 ff. and P. Sargos, 'L'Homme n'Est pas une Ile' 86 ff. See also J.R. de La Tour, 'La Vie Personnelle du Salarie', Report of 1999, available at http://www.courdecassation.fr/jurisprudence_publications_ documentation_2/publications_cour_26/em_rapport_annuel_em_36/rapport_1999_91/etudes_docume nts_93/jean_richard_5796.html.

${ }^{83}$ Craig, n 2 above, 94. A similar stance is adopted by German courts in cases of freedom of expression. See Finkin, n 2 above, 969.

${ }^{84}$ Painsecq v Association Fraternite Saint-Pie X, Cour de Cassation, Chambre Sociale, Decision 1704, 17 April 1991

${ }^{85}$ Mazurais $\mathrm{v}$ AIMT, Cour de Cassation, Chambre Sociale, Decision 2210, 21 October 2003, reprinted in Droit Social, $\mathrm{n} 2$ above, 30.

${ }^{86}$ Cour de Cassation, Chambre Sociale, Decision of 12 January 1999. 
to parents or colleagues. ${ }^{87}$ An issue of appearance regulation was addressed in Smith v Safeway, 88 a domestic pre-HRA case that involved dismissal for failure of a male employee to wear his hair not below collar length, contrary to the employer's wish. The resulting complaint that dismissal was discriminatory and unfair was rejected at first instance, and yet importantly, in allowing the appeal the employment appeal tribunal ruled that an obligation to have short hair affects the employee's life not only within the workplace, but also after work. ${ }^{89}$ The same line of argument underlies the admissibility decision of the European Commission of Human Rights (EComHR) in Kara v UK. ${ }^{90}$ Mr Kara's complaint that his dismissal by the Hackney Council because he dressed in female clothes at work breached article 8 was unsuccessful. Yet, in rejecting his application, the EComHR placed special weight on the fact that 'the rules as to the mode of dress at work affected the applicant during work, hours on work premises and that at other times he remained at liberty to dress as he wishes'. ${ }^{91}$

That a strict test is appropriate when looking at leisure activities presented as reasons for termination of employment seems to be uncontroversial in other jurisdictions. Yet UK case law accepted without much hesitation private activities that employers disapproved of on moral or other grounds as a legitimate ground for termination of employment, without fully appreciating the importance of a clear division between life at work and life after work - a position that in my view ought to be revisited. A final clarification is due at this point. In the section that follows I wish to claim that though a strong commitment to the temporal division is more likely to suit the employment context, certain exceptions may be justified.

\section{EXCEPTIONS TO THE TEMPORAL ELEMENT}

The heart of my argument is that life after work may lead to lawful dismissal only if there is a clear and present impact or a high likelihood of such impact on employment, whilst a speculative and marginal danger does not suffice. When having to justify termination of employment, the employer has to demonstrate the impact with precise evidence, so as to show that it is not only triggered by its views about morality and its disagreement with the employee's life choices. ${ }^{92} \mathrm{By}$ adding this stringent requirement that life after work has a precise impact on employment in order to be a legitimate ground for dismissal, we recognise that the relevant activities cease to be protected by a strong claim to privacy, which covers life after work.

\footnotetext{
${ }^{87}$ Finkin, n 2 above, 970.

88 Smith v Safeway, [1995] ICR 472.

89 The decision of the EAT was overturned by the Court of Appeal [1996] ICR 868 that found the rule justifiable. Another interesting example that involved antidiscrimination legislation, rather than the HRA, is Redfearn v Serco, [2006] ICR 1367, analysed by L. Cariolou, 'The Right not to Be Offended by Members of the British National Party: An Analysis of Serco Ltd v Redfearn in the Light of the European Convention on Human Rights', (2006) 35 ILJ 415.

${ }^{90}$ Kara v UK, App. No. 36528/97, Admissibility Decision of 22 October 1998.

91 ibid, under 'The Law', [1], emphasis added.

${ }^{92}$ For a similar approach see Waquet, n 82 above, 28.
} 
Case law of the ECtHR on dismissal lends support to the view that life after work should not affect retention of employment, but for circumstances where a direct impact on performance is demonstrated. This position is instantiated in Vogt v Germany. ${ }^{93}$ Scrutinising dismissal of a school teacher due to her political beliefs that on the view of the Respondent breached her duty of loyalty of German civil servants, the Court opined that ' $[\mathrm{s}$ ]ince teachers are figures of authority to their pupils, their special duties and responsibilities to a certain extent also apply to activities outside school'. Attention was placed on a certain risk consisting in the possibility that, contrary to the special duties and responsibilities incumbent on teachers, she would take advantage of her position to indoctrinate or exert improper influence in another way on her pupils during lessons'. ${ }^{94}$ Ms Vogt did not engage in such conduct at work, and Germany was held to breach its international duties.

It is moreover suggested that if the reasons for dismissal consist in sex-related activities or sexual preferences that might have an impact on the reputation of the employer, the threshold should be set even higher. Employers' concerns that any such behaviour will adversely affect their reputation should be tested with scepticism for reasons that this article attempted to illustrate in exploring the importance of privacy and sexual intimacy for individual autonomy. Societal prejudice on sex-related matters has historically been widespread, as was exemplified in Smith and Grady v $U K,{ }^{95}$ where the applicants were discharged from the armed forces because of their sexual orientation. In examining their complaint, the ECtHR stressed that the applicants' discharge stemmed primarily from a 'predisposed bias on the part of the heterosexual majority against a homosexual minority 96 rather than concrete evidence that they could not perform their job. The UK, therefore, violated the Convention.

Interestingly, French courts maintain a further distinction based on the character of an enterprise, when looking at the impact of life outside the workplace and working time on employment, by drawing a line between 'ordinary' enterprises ('enterprises ordinaires') and 'ideological' enterprises ('enterprises de tendance'). In ideological enterprises, which promote a particular ideology or ethic, personal freedom for activities outside work may be restricted ${ }^{97}$ through reliance

93 Vogt v Germany, App. No. 17851/91, Judgment of 2 September 1996. See also Ivanova v Bulgaria, App. No. 52435/99, Judgment of 12 July 2007. A similar stance is adopted by German courts in cases of freedom of expression. See Finkin, n 2 above, 969. Cf. Glasenapp v Germany, App. No. 9228/80, Judgment of 28 August 1986, and Kosiek v Germany, App. No. 9704/82, Judgment of 28 August 1986. These distinguish dismissal from access to work.

${ }^{94}$ Vogt, $\mathrm{n} 93$ above, [60].

95 Smith and Grady v UK, App. Nos. 33985/96, 33986/96, Judgment of 27 September 1999. See also Lustig-Prean and Beckett v UK, App. Nos. 31417/96 and 32377/96, Judgment of 27 September 1999. A long list of similar cases were recently partly struck out of the list, because of the Government's willingness to comply with the Court's findings. See, for instance, MacDonald v UK, App. No. 10600/05, Admissibility Decision of 11 December 2007.

96 Smith and Grady, n 95 above, [97].

${ }^{97}$ De La Tour, n 82 above. For criticism of this distinction, see Waquet, n 82 above, 26. Some parallels can be drawn between this position and the UK position in the anti-discrimination legislation in the example of exceptions to discrimination, involving genuine occupational requirements. See L. Vickers, 
on an implicit or explicit term in the employment contract that limits the individual employee's liberty. A similar position was endorsed by the EComHR in Rommelfanger $\mathrm{v}$ Germany, ${ }^{98}$ where a Catholic Church hospital terminated the applicant's employment as a physician, for the sole reason that he expressed views on abortion contrary to those of the Church. The EComHR proposed that such interference is not illegitimate, when 'the employer is an organisation based on certain convictions and value judgments which it considers as essential for the performance of its functions in society'. Painsecq may again usefully be considered here, where the Cour de Cassation stressed that dismissal is only lawful, if the employee's conduct undermines the convictions of the employer.

A possible objection that I would wish to anticipate involves criminal activities. It could be argued (and was suggested by Mummery LJ in $X \mathrm{v} Y$ ) that dismissal is lawful if the employee has committed a criminal offence. Criminal activities are never private on this view; they are of interest to the public, and this is why we should deem that dismissal for such behaviour is lawful. Yet, my position is that the criminal character of an activity is not necessarily apposite to fairness in dismissal. This can be illustrated by a variety of examples: theft by a cashier employed by a supermarket, or possession of child pornography by a person employed by a nursery. Both illustrate how a crime may be directly relevant to the nature of a job. In other situations, nonetheless, a criminal conviction may be irrelevant to the retention or access to employment. This approach is supported by the decision of the ECtHR in Tblimmenos $\mathrm{v}$ Greece. ${ }^{99} \mathrm{Mr}$ Thlimmenos was a Jehovah's Witness, a religious group committed to pacifism, and was convicted under Greek legislation for refusing to wear a military uniform for the purposes of his mandatory military service. Because of his conviction, he could not obtain a job as a chartered accountant, although he had been successful in the examinations. The ECtHR held that the facts of the case fell within the ambit of freedom of religion and constituted a violation of article 14 in conjunction with article 9. It stated that prohibition of discrimination is also violated when States without an objective and reasonable justification fail to treat differently persons whose situations are significantly different.'100 $\mathrm{Mr}$ Thlimmenos' criminal conviction, unlike other convictions that could have set an obstacle in performing his job as an accountant, should not have been used to justify his exclusion from the body of chartered accountants. A criminal conviction is not a safe criterion, in other words, because it may frequently be unrelated to a person's employment. To this, it should be added that activities are sometimes wrongly criminalised, as the

'Freedom of Religion and the Workplace: The Draft Employment Equality (Religion or Belief) Regulations 2003' (2003) 32 ILJ 23, 26 ff.

98 Rommelfanger $\mathrm{v}$ The Federal Republic of Germany, App. No. 12242/86, Adm. Dec. of 6 September 1989.

99 Thlimmenos v Greece, App. No. 34369/97, Judgment of 6 April 2000. French law adopts a similar approach. See, for instance, $C E A$ v Bouriane, Cour de Cassation, Chambre Sociale, Judgment of 26 February 2003, reprinted in Droit Social, n 2 above, 29. For further analysis of this issue, see E. Fortis, 'Vie Personnelle, Vie Professionnelle et Responsabilités Pénales', Droit Social, n 2 above, 40 ff.

100 Thlimmenos, $\mathrm{n} 99$ above, [44]. 
cases of $X \mathrm{v} Y$ and Thlimmenos remind us, providing a further reason why they should be investigated with caution in cases of dismissal.

To summarise my position, I endorsed the approach that presents the right to private life as a right to control information, rather than a right to act in spatial isolation. I further argued that in employment, the legal right to control information on private life might be better safeguarded, when bearing in mind the power of the employer to dominate the employee by imposing on her choices that are unrelated to the contractual relationship of the parties. Imposition of such obligations is illegitimate for it takes advantage of the inequality of power and the economic dependence of the employee. I then contended that an emphasis on a division between life at work and life after work might be a useful additional criterion when scrutinising fairness in dismissal. This separation implies that employees have a strong claim for protection when they engage in activities in their leisure time, and only accepts a narrow scope for exceptions to the temporal element, which should probably be limited to behaviour that has a real and present impact or a high probability of such impact on workplace performance. A real or potential effect on reputation should be scrutinised with special caution when the reason for dismissal concerns a person's sex life in particular.

\section{CONCLUSION}

The main criterion articulated by domestic courts and tribunals ought to be reconsidered, revisiting the cases presented in the introduction of this article. In the determination of the fairness of Mr X's and Mr Pay's dismissal, great emphasis was placed on the location of their acts - a spatial element as the main factor of what constitutes unprotected public life as opposed to private life that should be shielded against employer interference. Courts and tribunals were insufficiently appreciative of privacy - a value that ought to be cherished deeply when exploring a person's life after work.

Yet, the termination of Mr X's and Mr Pay's employment was unlawful. They were dismissed because they engaged in conduct that they considered fulfilling in their life after work, in their private time, the significance of which courts and tribunals fell short of appreciating. They did not employ a stringent test to the employers' decision, notwithstanding that both were dismissed for reasons that involved sex-related activities, against which the employers and society at large are often prejudiced. Mr Pay's employer opposed his personal choices on moral grounds, which seems to have constituted the primary reason behind his dismissal, for no evidence of adverse impact on his performance or the reputation of the probation service existed. In $X \mathrm{v} Y$, in finding that article 8 of the Convention is not applicable, the Employment Appeal Tribunal mentioned (with some disapproval, it seems) that the act for which $\mathrm{Mr} \mathrm{X}$ was cautioned was a transitory sexual encounter with a stranger. But it is hard to assess how the transitory 
character of the encounter and the participation of a stranger is relevant to the determination of whether his behaviour was an essential element of his most intimate private life. As to the question of the effect on the reputation of the charity that employs someone whose name figures in the Sex Offenders Register, two points ought to be raised. First, we ought to recall that Mr X's behaviour was wrongly criminalised and was later decriminalised; second, we should not overlook that when exploring the impact of sex life on the employer's reputation the threshold is to be set high. Societal prejudice is widespread and the role of human rights law is to protect minorities and vulnerable groups that fall victims of it.

Life after work is valuable, for it is our time to act autonomously, to develop meaningful relationships with others and to engage in activities that we find gratifying, without fear that these may impact on the retention of our job with all its devastating implications. Employers' intrusion can have a damaging effect on our liberty and autonomy: it can threaten enormously our work/life balance, it can harm our relations of love, friendship and trust, as well as all intimate relations that most of us value. Termination of employment because of our life after work can lead to a relationship of domination.

My article questioned the position adopted by courts and tribunals when looking at private life and dismissal. The fear articulated was that the current conception of privacy in dismissal for activities outside the workplace and working hours, was based on a misguided spatial understanding, which pays insufficient attention to the power of the employer to dominate the employee. I therefore suggested that a temporal, rather than a spatial, distinction between life at work and life after work may provide a more appropriate criterion in a fresh approach to leisure activities - a criterion that serves, I ought to note again, as a heuristic device. My claim is that our life outside the workplace and working hours is in principle an essential element of our private life that should be protected against external preferences, so as to prevent employers' domination. And while the introduction of a temporal element as a useful parameter in the current context appears to be more promising than spatial isolation, still I recognise that a number of complex questions remain. Modern forms of flexible employment, for instance, may pose additional challenges to the temporal element, and at the same time activities performed while at work are sometimes deemed private. Other possible invasions of privacy, such as genetic testing, cannot probably benefit from the temporal distinction I introduced, and might give rise to further questions of consent. Notwithstanding, the idea that private information may only be used if directly relevant to the performance of contractual duties could be of some use in addressing such legal and theoretical problems. For these reasons and a variety of others, the temporal element serves as an additional useful, albeit not conclusive, consideration, which will hopefully inspire debate. But none of these questions can be tackled unless we acquire a deep understanding of privacy, or, more precisely, the rationale of the value of privacy in human rights and labour law.

The incorporation of the ECHR into UK law has not as of yet triggered a watershed change of the law on unfair dismissal at least insofar as private activities 
are concerned, to conclude with a more general proposition. Progress can still 'be measured in inches rather than miles', as Ewing predicted a decade ago. ${ }^{101}$ Yet I hope to have indicated that human rights law can provide a useful tool to employment law. The prohibition of unfair dismissal, interpreted in light of the right to private life properly construed, can shield an individual employee against employer domination - a possibility that we lacked prior to the incorporation of the Convention. Human rights law can show new paths for the protection of workers' rights, contrary to the view commonly held by labour lawyers in the past. Yet an essential first step must involve exploring the values that underlie the two areas of law, before construing civil liberties at work according to these values.

${ }^{101}$ K.D. Ewing, ‘The Human Rights Act and Labour Law' (1998) 27 ILJ 275, 288. 